\title{
EMOÇÕES, MEMÓRIAS, RELATOS E PESQUISAS
}

Esta terceira edição da e-Mosaicos - Revista Multidisciplinar de Ensino, Pesquisa, Extensão e Cultura do Instituto de Aplicação Fernando Rodrigues da Silveira traz uma singela, mas extremamente afetuosa, homenagem a alguns dos (ex)professores e ex-alunos que fizeram história e a história nos 40 anos de Olimpíada desta Instituição.

40 anos são uma marca em uma vida. E em uma trajetória. Contar a história desses 40 anos, pelos olhares e pela memória de quem a criou, a fez e a viveu e vive intensamente, foi uma escolha da editoria da e-Mosaicos, pois representa registrar a memória pelas lentes de quem fez e é parte dessa trajetória. Agradecemos imensamente aos entrevistados - Celby, Raul, Miragaya, Aristônio, Denise e Ivan - e aos professores Esequiel Oliveira, Lincoln Tavares e Sônia Wanderley, os entrevistadores que aceitaram o desafio de reunirem essas ilustres pessoas que são parte da história do Instituto de Aplicação. Ficamos muito felizes!

Na seção "Artigos", as questões da escola e das concepções de educação se apresentam no cenário desta edição. Os dois primeiros artigos abordam a ética nos PCNs e na sala de aula e reflexões a partir de Bourdieu e as concepções de educação, considerando o papel da escola, frente a um cenário de desigualdades e são de autoria de Rita Josélia da Capela e Terezinha Regina Nazar Nogueira, e de Walace Ferreira, respectivamente. Apresentamos também ao leitor o percurso de ser estudante e pesquisadora e a contribuição dessa vivência para o conceito de formação docente, contribuição de Naila de Figueiredo Portugal e Jacqueline de Fátima dos Santos Morais. Na sequência, Cláudia Cristina dos Santos Andrade e Esequiel Rodrigues Oliveira discutem o uso da tecnologia com o recurso da imagem em sala de aula, trazendo para a revista um registro de um curso de extensão universitária realizado no CAp-UERJ. As pesquisas educacionais e as questões epistemológicas vêm à cena por meio do artigo de Adolfo Ramos Lamar e Jacson Tiedt, que aborda autores colombianos e as relações entre epistemologia, educação e pedagogia. Os livros didáticos do Ensino Fundamental e Médio e a abordagem do conceito de fotossíntese são discutidos por Bárbara Balzana Mendes Pires, Lidiane Aparecida Almeida e Maria Beatriz Dias da Silva Maia Porto e encerram essa seção.

Convidamos ainda o leitor a conhecer as duas resenhas. A primeira de autoria de Augusto César Pinheiro da Silva e a segunda de autoria de Desiré Luciane Dominschek e Ana Laura da Silva Teixeira são, com certeza, um convite a essas outras leituras.

Então... boa leitura!

Andrea da Paixão Fernandes Editora Geral 